\title{
The stolen veteran: institutionalisation, military service, and the Stolen Generations ${ }^{1}$
}

\author{
Noah Riseman
}

Lance-Corporal David Cook is an Aboriginal man of mixed descent born in Ebor in the New England region of New South Wales on 16 May 1945. This is the borderland of the Djungutti and Gumbaynggirr peoples, but Dave Cook does not self-identify with any particular Aboriginal mob. Around the time of Dave's tenth birthday, he and his four siblings were removed from their parents. Dave was placed in Kinchela Boys Home for three years before being fostered out with three of his sisters. At the age of 17 Dave enlisted in the Army; he served two tours of duty in Vietnam before being discharged in 1968. Though a successful soldier liked by his peers, Dave's life spiralled downhill in the 1970s. Cycles of violence, imprisonment, and racism threatened to turn him into another Aboriginal statistic until he got his life back on track through reconnecting with his siblings.

This article uses the prism of Dave Cook's life story to analyse the relationship between the armed forces and the Stolen Generations. Little research has been conducted in the history of Indigenous service, and even less on Indigenous service post-Second World War. ${ }^{2}$ The dominant argument proposed by Robert Hall and other historians is that military service provided new social and economic opportunities for Aboriginal and Torres Strait Islander advancement, as witnessed in high-profile Second World War Indigenous veterans such as Oodgeroo Noonuccal (Kath Walker), Reg Saunders, and Charles Mene. ${ }^{3}$ This argument certainly has merit, and among the testimonies of veterans of Korea, Vietnam, and the Gulf War, and other ex-service personnel, similar themes of new economic opportunities, learning skills and contributing back to their Indigenous communities have permeated ex-servicemen and women's

1 As a warning to any Indigenous readers, this article uses the names of persons who are deceased. It also discusses some very sensitive Stolen Generations material such as abuse and welfare files. The author gratefully acknowledges the financial assistance of the Army History Research Grant, Dave Cook and his family's generosity and the constructive suggestions of the two referees.

2 The only source that significantly examines Indigenous service post-Second World War is the documentary The Forgotten 2003. Other sources that address aspects of Indigenous service postSecond World War include: Carroll (RL) 1992; Jackomos and Fowell 1993; Stasiuk 2004; Smith 2001; Kartinyeri 1996; Moremon 2003; Bray, Laughton and Forster 1995; James 2010. The most comprehensive histories of Indigenous service during the Second World War are Hall 1997; Ball 1991. For the First World War see Winegard 2009; Huggonson 1993; Pratt 1990.

3 See Hall 1995; Gordon 1965; Ramsland and Mooney 2006: 179-201. 
life stories. ${ }^{4}$ But there is one commonality among the majority of documented cases in which Dave Cook does not fit: they were not forcibly removed from their parents as children and thus were not members of the Stolen Generations. Certainly their lives were subject to discrimination, but they maintained their family connections and some sense of personal autonomy and agency over their own lives.

This was not the case in the life of Lance-Corporal David Cook. Instead, Cook's life followed many of the common trends among Stolen Generations survivors as outlined in the Bringing Them Home report (1997) and the Royal Commission into Aboriginal Deaths in Custody (1991). In Cook's case, while his experience in the Army was positive and free of racism, it did not provide the escape and new opportunities commonly touted among historians of Indigenous service. Contrarily, the Army was an environment where Dave thrived because it prolonged his institutionalisation. He was treated as an equal, but at the same time it could not undo the damage that had been done to him as a result of being Stolen. After his service in Vietnam, Dave Cook went on a negative trajectory through prison, family violence, and confronting both de jure and de facto discrimination. Dave Cook's life story suggests that while the armed forces did provide many significant opportunities for Aboriginal and Torres Strait Islander advancement in the post-Second World War era, when it came to the Stolen Generations the military was not necessarily an escape from the institutionalisation and long-term trauma so prevalent among survivors of removal.

\section{Historiography and methodology}

Before delving into Dave Cook's life, a few preliminary comments are necessary on the historiography of links between the Stolen Generations and the armed forces. Social welfare historians have indicated that enlisting in the armed forces was not uncommon for survivors of out-of-home care. The military provided a steady job with a steady income and accommodation, and the regimentation and discipline mirrored the institutionalisation experienced through the welfare system. This trend applies not only to the Stolen Generations, but also to other removed and institutionalised groups such as the Forgotten Australians. ${ }^{5}$ When looking at Indigenous service in general, there are no clear numbers of Aboriginal and Torres Strait Islander service personnel because prior to 1993 the armed forces did not record the race or ethnic background of enlistees. In 1993 there were 697 Indigenous full-time members of the Australian Defence Force, making up a little over one percent of the total services. ${ }^{6}$ Yet the exact number of Indigenous people who served in conflicts such as Korea or Vietnam

4 The Forgotten 2003; Jackomos and Fowell 1993; Bray, Laughton and Forster 1995; I Hope the War Will be Over Soon 1988; Bostock 1991, 'Black Veterans of Vietnam', unpublished manuscript, Australian Institute for Aboriginal and Torres Strait Islander Studies [hereafter AIATSIS].

5 Commonwealth of Australia 2004: 161; Murray et al 2008: 132-133.

6 Smith 2001: 136. 
is unknown. ${ }^{7}$ It was service in these conflicts, as well as the First and Second World Wars, during which Stolen Generations members would be among the ranks of Australian Defence Force personnel.

Though there are no clear statistics, there is anecdotal evidence and oral testimony that suggest the armed forces were a destination for numerous Stolen Generations survivors. Yet only a few historical sources have mentioned the armed forces in the context of Stolen Generations. Peter Read has presented excerpts from Stolen Generations survivors who enlisted in the Army or Navy. ${ }^{8}$ The Bringing Them Home report makes one mention of the Army in a submission from the Northern Territory that reads: 'I worked there for seven and a half years, never got paid anything, all that time... So I had to join the army to survive'. 9 A handful of Stolen Generations biographies - such as Rob Riley's and Alec Kruger's - mention military service; interestingly, though, in these biographies military service plays a minor role in the Stolen Generations members' wider life stories. ${ }^{10}$ Beyond these minor mentions of the armed forces, there is no indication as to the fate of those individuals who served. Dave Cook's story sheds some light on the experiences of those Stolen Generations service personnel.

The methodology behind this article is quite complex for numerous reasons. First and foremost, the mere nature of the Stolen Generations and the personal nature of Dave Cook's life story require sensitivity. The main primary sources for this article are oral testimony, Dave Cook's welfare file and his service records, in conjunction with key Stolen Generations documents such as the Bringing Them Home report. The article takes the approach of contextualising and juxtaposing Dave's oral history narrative with written primary and secondary sources because, as oral historian Alistair Thomson cautions, oral historians interviewing veterans need to be critically aware of the interviewees' motivations for participating, the form of narrative and the impact of public memory on the participants' recollections. Thomson suggests that such critical awareness 'will make more careful and nuanced use of personal testimony in their [historians'] reconstruction and interpretation of historical events: what happened, how and why it happened, what it felt like and meant for participants'. ${ }^{11}$ When I interviewed Dave, he was quite adamant that he wants his life story shared and is comfortable having the sensitive, personal details of his life disclosed because he wants Australians to understand the impact of the Stolen Generations on Aboriginal people and the Vietnam War on veterans; for this very reason Dave provided a copy of his welfare file and Department of Veterans' Affairs health records.

7 Staff at the Australian War Memorial are currently tracking service numbers of all identified Indigenous service personnel in all Australian conflicts. For Korea, the Australian War Memorial has identified approximately 35 Aboriginal and Torres Strait Islander service personnel and for Vietnam approximately 260.

8 Read 1999: 91, 138.

9 National Inquiry into the Separation of Aboriginal and Torres Strait Islander Children from their Families (Australia) 1997: 114

10 Beresford 2006; Kruger and Waterford 2007.

11 Thomson 2006: 20. 
The other complication is my position as a non-Indigenous academic researching Indigenous history. Clare Bradford wisely remarks:

[t]o speak for any group without being a member is a chancy move to make, but to speak for people formerly colonised is to replicate colonial processes which assume that "we" know what "they" think and desire. ${ }^{12}$

To avert the risks of re-colonising Dave Cook's story, this article centres Indigenous persons - Dave Cook in particular - as the primary actors rather than as passive objects in the wider historical context. The privileging of Aboriginal voices aligns with Indigenist methodological aims to focus:

on the lived, historical experiences, ideas, traditions, dreams, interests, aspirations, and the struggles of Indigenous Australians. Indigenous Australians are the primary subjects of Indigenist research. Indigenist research gives voice to Indigenous people..$^{13}$

Significantly, as the author is non-Indigenous, this article could not be classified as Indigenist or applying Indigenous Standpoint Theory. ${ }^{14}$ Yet the aims and outcomes of this research adhere to the principles of such research methodologies, working through a collaborative approach between non-Indigenous academic and Indigenous active participant. ${ }^{15}$ Oral historian Heather Goodall writes:

[t]he public work which leads us into genuinely new relationships will be that which poses questions on which diverse groups of people want to collaborate and which fosters a strong enough sense of confidence to allow an exploration of complexities and ambiguities. ${ }^{16}$

While there are some conclusions which can be drawn from this article, I hope that, following Goodall's suggestion, it will open a space for further dialogue, inquiries into Indigenous military service and/or the Stolen Generations and collaborative research partnerships between Indigenous and non-Indigenous people.

\section{Dave Cook's stolen childhood}

David Cook spent his early childhood living with his mother, father, five sisters and a younger brother; Dave was the second child. He does not recall much of his life before removal, nor does he discuss the actual forced removal of himself and his siblings. Dave's welfare file indicates that he was removed around his tenth

12 Bradford 2001: 133.

13 Rigney 1999: 117. See also Foley 2003.

14 For Indigenous Standpoint Theory, which is similar to Indigenist research methodology, see Nakata 2007; Foley 2005-06; Tuhiwai Smith 1999.

15 See Somerville and Perkins 2003.

16 Goodall 2002: 24. 
birthday in 1955 and placed at the notorious Kinchela Boys Home in Kempsey, New South Wales, for three years. Enough has been documented about Kinchela to suggest that these were probably very hard years. Dave recalls:

[I]f you played up in Kinchela Boys Home, if you done something that you shouldn't've done, your punishment - they - all the boys would be lined up, and the punishment used to happen when you go to, um, lunch, or dinner, or tea. They all lined up, and you have to walk down the line, and they've gotta hit ya. They can't hit ya in the face; they punch you in the chest, in the belly [makes smacking sound]. And if you didn't hit hard enough, you'd go up the end of the line. ${ }^{17}$

Cook's testimony aligns almost perfectly with other accounts of this ritual, ${ }^{18}$ and other Aboriginal testimonies describe graphic incidents of physical and sexual abuse that occurred at Kinchela. ${ }^{19}$

Kinchela was also the site of institutionalised labour for the Aboriginal boys. Cook describes how they did not receive an education, but rather worked in the gardens and tending to livestock such as cows. ${ }^{20}$ As Peter Read indicates, 'the work the boys were compelled to do, such as scrubbing and washing, was not the life of normal healthy boys' ${ }^{21}$ Institutionalisation at Kinchela went beyond the rigidity of labour. The residents were referred to by numbers instead of by names. Routine, structure, and hierarchy were strictly enforced at Kinchela, and this had a profound impact on the Aboriginal residents. ${ }^{22}$ Marlene J Norst describes the institutionalised Stolen Generations members at Kinchela as 'captives ... totally "removed" from their own cultural traditions - languages, beliefs, ways of seeing and doing - and then actively encouraged to despise and to feel shame rather than pride in their roots' ${ }^{23}$ In regards to Dave Cook, one letter from Kinchela would later state, '[w]e remember him as an excellent type of boy during his period of three years residence at Kinchela'.$^{24}$ Thus Dave Cook ostensibly succumbed readily to this regime and became an institutionalised man.

17 Cook, David, interview with Noah Riseman, Raymond Terrace, New South Wales, 20 January 2010, transcript: 16.

18 Simon et al 2009: 31-41; Norst 1999: 20; National Inquiry into the Separation of Aboriginal and Torres Strait Islander Children from their Families (Australia) 1997: 166.

19 National Inquiry into the Separation of Aboriginal and Torres Strait Islander Children from their Families (Australia) 1997: 160, 166-167; Read 1999: 68; Simon et al 2009: 41-47; Norst 1999: 20; Ramsland 2004: 102-103; Ramsland 2006: 237-248; Harrison 2002: 8.

20 Cook, interview with Riseman, 2010, transcript: 1. See also Simon et al 2009: 24-31; Harrison 2002: 10-11.

21 Read 2009: 153.

22 National Inquiry into the Separation of Aboriginal and Torres Strait Islander Children from their Families (Australia) 1997: 166; Simon et al 2009: 20-62; Haebich 2000; Who Killed Malcolm Smith? 1992.

23 Norst 1999: 22.

24 AF White, Manager, Aboriginal Boys' Training Home, Kinchela, 9 June 1961. 
After his three years at Kinchela, Dave Cook was fostered to a Mrs Smith ${ }^{25}$ of Allworth outside of Newcastle. ${ }^{26}$ Describing the impact of life after institutions such as Kinchela, Norst writes:

Having successfully been made to believe that black was white, they were then thrust defenceless into the 'real' white world where their assimilation proved to be an illusion and they were despised for being black. Here they found no acceptance and felt completely disoriented. ${ }^{27}$

The feelings of being an outcast and confrontations with racism most certainly were the case for Dave Cook. He testifies that he was taunted because of his race, but he was able to fit in with 'New Australian' migrant youth who were also derided by locals. ${ }^{28}$ Cook's comments inadvertently align with a critical argument pursued by historian Anna Haebich - that although the histories of Indigenous people and ethnic minorities during the assimilation period from the 1950 s to the 1970s were most certainly different, there are parallel developments within the history of assimilation 'of these different groups who were subject in varying degrees to the assimilatory pressures of nation building at the time' ${ }^{29}$

Cook was fortunate that three of his sisters were also fostered to Mrs Smith, but their younger brother remained at Kinchela. Living with Mrs Smith, Cook's life continued down a path common to many Stolen Generations survivors. The NSW Aborigines Welfare Board reports consistently described Cook as 'very well clothed', 'very well behaved' and 'very kindly treated'. The reports indicated that Cook was 'not very bright in school' but that he was 'happy and well' ${ }^{30}$ Dave Cook's testimony supports the reports that he was not physically abused, but he certainly contradicts the idea of being content. Cook suggests that Mrs Smith simply fostered him and his sisters as a source of income. He recalls being kicked out of home by Mrs Smith, though he does not indicate why. ${ }^{31}$ Correspondence between Mrs Smith and the Aborigines Welfare Board suggests that Cook would not 'obey her' and thus she could not have him in her home. ${ }^{32}$ Instead, Cook was taken in by the Thomas ${ }^{33}$ family. The Thomas' assessment was quite different from Mrs Smith's, writing that they were 'deeply concerned for

25 Name changed to protect identity.

26 Peter Read points out that from 1957, the New South Wales Aborigines Welfare Board advertised for foster parents, considering fostering a more economic alternative to running institutions such as Kinchela. See Read 1999: 62-64. For a history of child removal in New South Wales, see National Inquiry into the Separation of Aboriginal and Torres Strait Islander Children from their Families (Australia) 1997: 39-55, 600-610; 'To Remove and Protect', AIATSIS, online, accessed 30 June 2010: <http:/ / www1.aiatsis.gov.au/exhibitions/removeprotect/index.html\#>

27 Norst 1999: 22-23.

28 Cook, interview with Riseman, 2010, transcript: 2.

29 Haebich 2008: 14.

30 'Inspection Report on Aboriginal Ward Boarded-out or placed as adopted boarder', 30 June 1958, 16 January 1959, and 4 June 1959.

31 Cook, interview with Riseman, 2010, transcript: 1-2.

32 Letter from Mrs Smith to Aborigines Welfare Board, 13 November 1961; Letter from EH Mason to Superintendent, Aborigines Welfare Board, 14 November 1961.

33 Name changed to protect identity. 
David's welfare \& aim to see that David is well cared for \& justly treated' ${ }^{34}$ The alleged behaviour problems that manifested during Dave's time with Mrs Smith coincide with the findings of the Bringing Them Home report about the impact of institutionalisation often leading to delinquency during adolescence. ${ }^{35}$ Though the records and Cook's testimony do not indicate the extent of delinquency, the diverging opinions of the Thomas family and Mrs Smith suggest that providing a supportive environment was more conducive to Cook's development. Dave Cook remained with the Thomas family until just after his 17th birthday, at which time he enlisted in the Royal Australian Navy. Dave never saw his father again, and he would only ever see his mother again twice when he was an adult. He remarks, '[t]here was nothing. It was like meeting a stranger' ${ }^{36}$

\section{Service in the Australian Defence Force}

Dave Cook says that he enlisted in the Navy as a form of escape. Whereas the documented experiences of other Indigenous service personnel have suggested the armed forces as an escape from government regulations, controls, reserve life, and discrimination, ${ }^{37}$ Cook's testimony suggests it simply was to escape the drudgery of his life. In fact, he claims that it was to escape his sisters, still living with Mrs Smith, whom he describes as demanding and thus making his life quite difficult. At that time Dave did not hold any grudge against the government for taking him away because he did not realise child removal was a phenomenon specifically targeting Aboriginal children across New South Wales. He recalls:

And I didn't know they treated the whole lot of the, uh the rest of the Aboriginals the way they treated us, cuz I was so young; $y^{\prime}$ know what I mean? And I kept saying, 'Why are they treating me like this all the time?' $Y^{\prime}$ know. And I thought it was a personal thing with me. ${ }^{38}$

Cook's points about self-doubt and his inability to see the 'big picture' of the policies of child removal are not surprising given the psychological impacts of being Stolen, the denigration of Aboriginality and the subsequent effects of institutionalisation on removed children's self-esteem. ${ }^{39}$

Dave Cook's time in the Navy was short-lived; he was soon discharged for failing his examination on completion of the Recruit Disciplinary course. There

34 Letter from Mr Thomas to EM Mason, 20 November 1961.

35 National Inquiry into the Separation of Aboriginal and Torres Strait Islander Children from their Families (Australia) 1997: 190.

36 Cook, interview with Riseman, 2010, transcript: 39.

37 Hall 1995; Jackomos and Fowell 1993; Bostock 1991, 'Black Veterans of Vietnam', unpublished manuscript, AIATSIS.

38 Cook, interview with Riseman, 2010, transcript: 32.

39 National Inquiry into the Separation of Aboriginal and Torres Strait Islander Children from their Families (Australia) 1997: 177-211. 
were also letters expressing problems with Cook's 'slovenly dress and habits' ${ }^{40}$ According to Cook, it was racism rather than a lack of discipline that drove him out of the Navy. He states:

And I was the only Aboriginal in the outfit, and there weren't many Aboriginals in- in the- in the forces. And, it didn't matter what I done, I just couldn't do it right. He just didn't want me in his outfit. He just- I was a blot on his- on his outfit, being Black. ${ }^{41}$

Testimony from an Aboriginal Korean War veteran suggests similar problems of racism preventing him from joining the Navy, and historian Jason Sear argues that the Australian Navy was the service that traditionally discriminated most against non-Europeans. ${ }^{42}$ Cook moved home for only a few months before he signed up again, but this time in the Army. Cook served in the Royal Australian Engineers in New Guinea and Borneo. In 1965 he volunteered to go to Vietnam attached to the 1st Battalion, Royal Australian Regiment. ${ }^{43}$ He did two tours in Vietnam in 1965-66 and in 1967-68.

The address on Dave Cook's attestation form reads 'Aborigines Welfare Board', ${ }^{4}$ indicating that it was still his legal guardian at the time of his enlistment. In fact, in Cook's Welfare file there is correspondence between the Aborigines Welfare Board and both the Army and Navy in relation to both Cook's behaviour and welfare. The Aborigines Welfare Board wanted confirmation that Cook had enlisted in the Army. ${ }^{45}$ Even after Cook's enlistment, his mother was sending letters to the Aborigines Welfare Board in an effort to communicate with him. Cook's mother clearly did not know that Dave had joined the Army, and the Welfare Board simply told his mother to contact Department of the Army. ${ }^{46}$ Yet the Superintendant of the Aborigines Welfare Board was still sending his own personal letters to Cook, indicating that he clearly had Cook's address in the Army. Thus the Aborigines Welfare Board continued to exert power over aspects of Cook's Stolen life, even as he seemingly escaped their control through enlistment in the armed forces.

When asked about racism in the Australian Army, Dave definitively declared: 'never once did I have any prejudice pinned on me in the Australian Army.

40 Lieutenant DG Bowen, RAN, to HJ Green, Aborigines Welfare Board, 6 September 1962; 22 August 1962, Dave Cook welfare file.

41 Cook, interview with Riseman, 2010, transcript: 2.

42 Egglestone, Private Cedric 'Ned' and Don McLeod, Royal Australian Infantry Corps 1998, interviewed by Bill Bunbury, 3 September 1998, RSL Reservoir, Australian War Memorial AWM S01907; Sears 2001: 71.

43 Record of Service, Cook, D, 214933, in Department of Veterans' Affairs Medical File, SS00205; David Cook service records, service number 214933, Central Army Records Office [hereafter CARO]; Cook, interview with Riseman, 2010, transcript: 3-6.

44 Application form for males for enlistent in - The Australian Regular Army, in David Cook service records, service number 214933, CARO.

45 HJ Green, Superintendant, to The Aborigines' Welfare Officer, 5 February 1963, Dave Cook welfare file.

46 Norma Cook, to HJ Green, Superintendant, 4 July 1963; HJ Green, Superintendant of Aborigines Welfare, to Miss Norma Cook, 19 July 1963, Dave Cook welfare file. 
Not once' ${ }^{47}$ This was the first time in Dave's life in which he was a complete equal with non-Indigenous people. In fact, not once in Cook's service records does the word 'Aboriginal' appear; ${ }^{48}$ this is common among service records of Aboriginal and Torres Strait Islander Korean War and Vietnam War veterans. Cook served in Vietnam with three other Indigenous people: Billy Coolburra from Palm Island, Torres Strait Islander Bill Unmeopa and a Yamatji man from Western Australia named Frank Mallard. ${ }^{49}$ Their Commanding Officer, Captain Sandy MacGregor, writes: 'they were rarely, if ever, subjected to racism. The strong bond between soldiers - and engineers in particular - transcended more obvious differences like colour and culture' ${ }^{50}$ Interestingly, both Coolburra and Cook have commented on the contrasting prevalence of racism in the United States Army. Dave states: ' $\mathrm{t}$ ] he whitefellas lived here, the blackfellas lived here. The blackfellas ate in this mess and the whitefellas ate in this mess ... Even the Australians were shocked at the racism that it was because they've never seen it so blatant' ${ }^{51}$ Other Aboriginal veterans have similarly commented on racism in the American Army. ${ }^{52}$ As this was not the case in the Australian Army, Dave saw it as an opportunity for escape from the problems he confronted in Australia. He even wrote to the Aborigines Welfare Board, expressing interest in seeing his brother, still at Kinchela. Dave wrote, 'I'm going to try \& get him to join the Army or Navy if he think he can or should'. ${ }^{53}$

Dave had quite an active time in Vietnam and received significant praise from his superior officers and peers. An early report from his basic training declared, '[a]n above average soldier - handles weapons well - could be developed into NCO material - very carefree nature - works well without supervision' ${ }^{54}$ Dave lived up to these expectations, as he was ultimately promoted to the NonCommissioned Officer rank of Lance-Corporal. Captain Sandy MacGregor writes: 'Dave was one of the wilder elements in the troop - but he was also one of the best forward scouts in the Australian Army'. ${ }^{55}$ Cook got himself into trouble on occasion. He recalls one particular incident during which he got into a brawl with several American soldiers in a bar, resulting in him being hauled away by American Military Police. ${ }^{56}$ Dave managed to miss the Battle of Long Tan by virtue of accidentally shooting himself in the leg two days prior. During

47 Cook, interview with Riseman, 2010, transcript: 9.

48 David Cook service records, service number 214933, CARO.

49 David Cook actually did not know that Frank Mallard was Aboriginal, nor is he mentioned as Aboriginal in Sandy MacGregor's book. Mallard is indeed Aboriginal, though, and comes from a Yamatji family with a strong tradition of Aboriginal service. Frank Mallard, interview with Noah Riseman, Northbridge, Western Australia, 24 November 2010; James 2010: 223-230.

50 MacGregor 1993: 81.

51 Cook, interview with Riseman, 2010, transcript: 6. See also MacGregor 1993: 85.

52 Bostock 1991, 'Black Veterans of Vietnam', unpublished manuscript, AIATSIS: 11-12; Bostock 1991, Interviews with Aboriginal Vietnam Veterans for proposed book 'Black Veterans of Vietnam', AIATSIS.

53 Letter from Dave Cook to Mr and Mrs Green, November 1963, Dave Cook welfare file.

54 'Individual Training - Progress Report', 6 March 1963, in David Cook service records, service number 214933, CARO.

55 MacGregor 1993: 85.

56 Cook, interview with Riseman, 2010, transcript: 7-8; MacGregor 1993: 85-87. 
his second tour of duty, he missed the Tet Offensive by virtue of being bitten by a scorpion. During the Tet Offensive, Cook's section was hit quite hard, with all but one soldier being wounded or killed. ${ }^{57}$ In Dave's own words, the psychological impact of missing Tet was enormous; he says: '[w]ell, I went over the hill. I went troppo. They sent me back to Australia' ${ }^{58}$ These Vietnam experiences of Cook's are not dissimilar to the histories of other Australian Vietnam veterans. ${ }^{59}$ Essentially, as Dave himself posits, the war experience was indeed similar to non-Indigenous Australians - for better and for worse. But it was upon his return to Australia and his discharge from the Army that the long-term impacts of being Stolen would re-manifest.

\section{Civilian spiral}

Like so many other Vietnam veterans, Dave Cook experienced Post-Traumatic Stress Disorder (PTSD) after his discharge in December 1968. He recalls the difficulty of adjusting from being in the jungle of Vietnam one day, and the next being at home in western Sydney with a partner and two screaming children. This new family was the result of relations Dave had with a woman in Australia during his time of service, and the two children were born while he was overseas. Dave says, '[t]he change was so terrific- horrific, y'know. I just couldn't handle it'. ${ }^{60}$ Stories of Vietnam veterans' difficulty adjusting to civilian life and experiencing PTSD are not uncommon and also transcend race and culture. ${ }^{61}$ Yet unlike most veterans, Dave had to deal with the compounded problems of confronting racism and entering a society for which his Stolen childhood had ill-prepared him. PTSD has not only been common among veterans, but also among Stolen Generations survivors. The Bringing Them Home report indicates that '[t]hese [removed] children are more likely to "choose" trauma-prone living situations in adulthood and are particularly vulnerable to the ill-effects of later stressors' ${ }^{62}$ Dave very candidly admits that his family and work life after Vietnam were volatile. He admits to being an ill-prepared and unfit father, which adheres to findings of the Bringing Them Home report about the intergenerational impacts of forced removal. ${ }^{63} \mathrm{He}$ admits to physically abusing his wife, which is how he first got into trouble with the police and entered the legal system. Cook does not attribute this violence to alcohol abuse, though, which was common among Army members in the 1960s-70s. ${ }^{64}$

57 Cook, interview with Riseman, 2010, transcript: 8-9.

58 Cook, interview with Riseman, 2010, transcript: 9.

59 See, for instance, Maddock 1991.

60 Cook, interview with Riseman, 2010, transcript: 11.

61 Department of Veterans' Affairs 1998-99; Burstall 1990; Giblett 1990; Maddock 1991. Kristy Muir discusses how PTSD has impacted veterans of not just Vietnam, but other conflicts as well. See Muir 2007; Muir 2003, especially 'Introduction'.

62 National Inquiry into the Separation of Aboriginal and Torres Strait Islander Children from their Families (Australia) 1997: 196.

63 National Inquiry into the Separation of Aboriginal and Torres Strait Islander Children from their Families (Australia) 1997: 222-226.

64 Cook, interview with Riseman, 2010, transcript: 13, 15; McGregor 2010: 192-193. 
Dave's unashamed bias against the police problematises some of his oral testimony about his legal problems. Nonetheless, much of what he recalls aligns with patterns presented by Bringing Them Home and the Royal Commission into Aboriginal Deaths in Custody, lending validity to much of his testimony. ${ }^{65}$ Dave acknowledges that he returned from the Army hating authority; when he encountered racist police officers, his post-Army confidence resulted in him retaliating rather than passively accepting police abuse. He also emphatically believes that police targeted him for being Black; he cites examples of police pulling him over while driving, hurling racist abuse at him and his wife, and often stacking charges against him that were unfounded and unrelated to his assaults. ${ }^{66}$ Problems of police stereotyping of Aboriginal people, verbal harassment and racial profiling were explicitly highlighted in the Royal Commission among the issues hindering positive relationships between Aboriginal people and police. As the Royal Commission succinctly summarised, 'far too much police intervention in the lives of Aboriginal people throughout Australia has been arbitrary, discriminatory, racist and violent' ${ }^{67}$ This was the experience for Dave Cook.

Dave does not deny committing crimes; he acknowledges:

I've been locked up, and, um, through violence. Iron-barring peoplehitting them with iron bars - they weren't, they were other people, $y^{\prime}$ know. And, uh, you just can't do that sort of things; I know that now-68

Dave spent much of the 1970s and 1980s in and out of prison as punishment for these assault convictions. The question at hand, though, is whether Dave's Army or childhood trauma led to this destructive life cycle. Certainly one cannot definitively say that it was one or the other, but a few pieces of evidence suggest that his Stolen childhood had more of an impact and that the Army trauma reinforced this. First, the links between child removal and Dave's offending patterns receive support from the Royal Commission and Bringing Them Home report. The Royal Commission determined that 'the legacy of child removal has had a distinct role to play in institutionalisation and consequent juvenile offending'. ${ }^{69}$ As early as 1982 the Australian Law Reform Commission similarly determined there to be a link between 'very high rates of Aboriginal juveniles in corrective institutions and of Aborigines in prisons' and 'their having been placed in substitute care as children' ${ }^{70}$ Dave's own experience in the criminal justice system also mirrors Royal Commission findings about the high proportion

65 Peter Read effectively points out that despite the biased nature of some oral testimonies, ' $[\mathrm{t}] \mathrm{he}$ answer is that the written records uphold them'. Read 1999: 173.

66 Cook, interview with Riseman, 2010, transcript: 12-13, 20.

67 Australia 1991: section 13.2.3.

68 Cook, interview with Riseman, 2010, transcript: 15.

69 Australia 1991: section 11.7.6.

70 Australian Law Reform Commission, Aboriginal Customary Law: Child Custody, Fostering and Adoption (Sydney, 1982), 6, in National Inquiry into the Separation of Aboriginal and Torres Strait Islander Children from their Families (Australia) 1997: 190. 
of Indigenous people in custody. Dave recalls: 'there's a lot- a lot of Aboriginals ... And it was the cream of the Australian Aboriginal youth back then was locked up. A whole generation of them, and it was sickening to see'.$^{71}$

The other evidence that suggests the Stolen Generations experience was the primary cause of Dave's post-Army spiral emerges through general studies of Australian Vietnam veterans, PTSD and the legal system. When asked if there were any other Vietnam veterans in prison, Dave could think of only one. He said, '[h]e was a white. But he was, uh, he was a lot worse than me. He was a man armed holdup. He used to run around doing armed holdups ${ }^{\prime} .^{72}$ The topic of Vietnam veterans and the Australian criminal justice system is clouded in myths and false constructions borrowed from the United States. Indeed, historians have found that many aspects of Australia's national myths surrounding the Vietnam War and the anti-war movement have been based falsely on United States' experiences. ${ }^{73}$ Similarly, myths about criminality and Vietnam veterans have transmitted from the United States to Australia. There is data from the United States that suggests that Vietnam Veterans suffering PTSD were overrepresented in the prison population. In 1975, for example, 30 per cent of adult male federal prisoners in the United States were Vietnam veterans. ${ }^{74}$ By 1987 it was estimated that up to 25 per cent of American men who saw combat in Vietnam had been charged with a criminal offence. ${ }^{75}$ This over-representation fuelled public perceptions of criminality and Vietnam veterans, and the popular perceptions transferred to Australia along with other American memories of Vietnam.

Yet the evidence suggests that there are no parallel correlations of Vietnam veterans and the criminal justice system in Australia. There is no mention of prison or criminality in the most comprehensive inquiry into the status of Australian Vietnam veterans conducted by the Department of Veterans' Affairs in 199899. ${ }^{76}$ A psychology study providing an overview of literature on both American and Australian Vietnam veterans and the problems of PTSD was published by Bruce Boman in 1982. This article focuses on PTSD and interrelated problems of personality changes, depression, substance abuse, and treatments for PTSD. Boman debunks the myth of criminality among Vietnam veterans: 'the amount of criminal behaviour among Vietnam veterans has been said to be no greater than what might have been predicted from their behaviour prior to entering military service' ${ }^{77}$ The only journal article even to address the question of PTSD, Australian Vietnam veterans and the legal system - published in 1987 - principally describes the United States experience. The article by Terry Shulze describes the rise of PTSD as a legal defence among American veteran defendants, which could have

71 Cook, interview with Riseman, 2010, transcript: 21.

72 Cook, interview with Riseman, 2010, transcript: 22.

73 See, for example, Grey 2010; Grey and Doyle 1992; Pierce, Doyle and Grey 1991.

74 Boman 1982: 119.

75 Shulze 1987: 38-40. For more information about American Vietnam veterans and the criminal justice system, see Erlinder 1984.

76 Department of Veterans' Affairs 1998-99.

77 Boman 1982: 120, emphasis added. 
potential ramifications in Australia. ${ }^{78}$ Yet despite sensationalist media accounts in the 1980s of Vietnam veterans allegedly committing crimes, the Minister for Veterans' Affairs Arthur Gietzelt reported a study in Victoria in 1983 which found that Vietnam veterans were disproportionately underrepresented amongst the prison population by approximately one-third. ${ }^{79}$ Thus it is clear from evidence - or rather lack thereof - that the stereotype of criminal behaviour being preponderant among Vietnam veterans is not applicable to Australia. The reasons for this divergence from the American experience of PTSD have not been adequately researched, and they are outside the scope of this article. ${ }^{80}$ What set Dave Cook apart from the majority of Australian Vietnam veterans - including other Aboriginal Vietnam veterans - was that he had been institutionalised even before he joined the Army.

The impact of institutionalisation on the Stolen Generations has already been well-documented. ${ }^{81}$ Bringing Them Home summarised:

Psychological and emotional damage renders many people less able to learn social skills and survival skills. Their ability to operate successfully in the world is impaired causing low educational achievement, unemployment and consequent poverty. These in turn cause their own emotional distress leading some to perpetrate violence, self-harm, substance abuse or anti-social behaviour. ${ }^{82}$

Dave Cook was one of the people that fell into this pattern. Dave Cook's service records include a psychological assessment given upon enlistment which highlighted extant mental health problems. The test was a series of yes/no questions, and the assessor noted ten responses which indicated cause for concern. The two questions that deserve mention here are: 'Do you feel like jumping when you are on a high place? YES' and 'Do you feel that your childhood was a happy one? $\mathrm{NO}^{\prime} .{ }^{83}$ Moreover, his original employment allocation after basic training commented, '[t]est results are average. A willing worker but appears easily misled. General appearance is average' ${ }^{84}$ These mental health problems did not preclude Cook from being an effective soldier, and in fact the Army regularly

78 Shulze 1987: 38-40.

79 Senator Arthur Gietzelt, Minister for Veterans' Affairs, in Parliament of Australia 1986.

80 Non-Indigenous Vietnam veteran Gary McKay suggests that Australian soldiers were more professionalised and had a better rotation system that fostered teamwork, unity and a sense of camaraderie among soldiers. McKay speculates, '[w] hen we came back we found that people on the whole imagined us to be like the Americans; but having seen the US Army in action, witnessed their lack of professionalism and the problems they had because of their draft and drugs, the Americans were the last people with whom we wanted to be compared.' McKay 1987: 188.

81 National Inquiry into the Separation of Aboriginal and Torres Strait Islander Children from their Families (Australia) 1997: 187-192; Read 1999: 190.

82 National Inquiry into the Separation of Aboriginal and Torres Strait Islander Children from their Families (Australia) 1997: 178.

83 Australian Army Psychology Corps: Test SDI, no date, in David Cook service records, service number 214933, CARO.

84 DP3 Employment Designation Training, 6 March 1963, in David Cook service records, service number 214933, CARO. 
enlisted men with low educational standards because it was difficult to attract applicants during an era of full employment. ${ }^{85}$ Nonetheless, the tests indicate that the Australian Army could already identify psychological problems even before Dave Cook was dispatched to Vietnam. Certainly one could argue that the Vietnam experience exacerbated mental health problems, but the original causes - being Stolen and institutionalised - predated his tours of duty, and the service records suggest that the Army merely noted the mental health problems without treating them.

\section{Wider ramifications of Dave Cook's life story}

Dave Cook's life was his alone; while aspects of his experience as a member of the Stolen Generations, a Vietnam veteran and an Aboriginal man in prison may mirror wider patterns, these relationships do not detract from his own feelings, his own memories and his personal development. While Dave Cook's life is the case study examined in this article, other sources affirm the argument that the armed forces merely prolonged the institutionalisation of Stolen Generations members. The story of Rob Riley, Noongar activist and civil rights advocate, highlights the ongoing trauma experienced by Stolen Generations ex-servicemen. Riley was removed from his family and placed in Sister Kate's Home in Perth. He too confronted racism when in the wider community and he too experienced abuse during his childhood. Later in life, Riley commented that his institutionalised childhood made him 'grow up thinking that we were totally alone in the world. We had no family, no belongings no identity' ${ }^{86}$ Rob joined the Army in 1973; fellow Sister Kate's inmate Sue Gordon recalls, 'Aboriginals from an institutional background felt comfortable in the army - and the army offered seconds at meal times, which did not happen at Sister Kate's!' ${ }^{87}$ Riley's experience in the Army was egalitarian like Cook's. He wrote in 1987, 'there was a system that everybody, no matter who it was, has to put up with, conform to' ${ }^{88}$ After his Army service, Rob Riley's life did not spiral downward like Dave Cook's. He received a tertiary education, became a leading member of the West Australian Aboriginal Legal Service and Chair of the National Aboriginal Council. Yet as Quentin Beresford writes, ' [o]utwardly he emerged [from the Army] self-assured and confident yet he bore hidden scars: the damage done by institutionalisation, sexual abuse, broken family ties and racial harassment' ${ }^{89}$ Ultimately depression stemming from the long-term impacts of Riley's traumatic childhood consumed him and tragically he committed suicide in 1996. Thus like the case of Dave Cook, even though his service in the Australian Army had a positive impact on his life, it did not overpower the damage of his Stolen childhood.

85 Grey 2001: 209-210.

86 Beresford 2006: 69.

87 Sue Gordon, quoted in Beresford 2006: 74. Non-Indigenous Australians from welfare institutions have expressed similar sentiments. See Murray et al 2008: 132.

88 Rob Riley, in Beresford 2006: 74.

89 Rob Riley, in Beresford 2006: 74. 
Dave Cook did manage to get his life back on track after serving six years in total in prison because of his determination to reconnect with his family. He says, 'I decided to come home, I rang me sister and they says "Yeah, come home and stay with us." Everything panned out'. ${ }^{90}$ He worked for his brother-in-law for much of the late 1980s-2000s. He is now retired and receiving a pension; at the time this article was written, Cook was in Cambodia assisting with land mine clearing under a program run by a fellow veteran. His relationships with his children are estranged, which he also attributes to his Stolen childhood. He remarks:

it's mainly because I got no love in me body. I can't love anybody; $\mathrm{y}^{\prime}$ know what I mean? I got no feelings for nobody ... I know I'd like to experience it, but I'm a little too old for it now. ${ }^{91}$

Dave's inability to make emotional attachments reflects the intergenerational impacts of child removal outlined in Bringing Them Home. ${ }^{92} \mathrm{He}$ does not confront racism anymore in his daily life, but he does recall key moments in recent years when he encountered racism. One such incident was during the time of Hansonism in the late 1990s - when One Nation Party founder Pauline Hanson tapped into public discontent over Aboriginal affairs and so-called special treatment - and resulted in a brawl in his hometown. The other major occurrence happened at a Vietnam veterans' reunion. While disagreeing with a fellow member of his Vietnam company, the gentleman retorted:

'Ah, you Black cunt!' Y'know. No one's ever said that to me. No one! ... So, out of all the guys I meet in the Army, there was no one - not nothing like that said - in Vietnam, maybe because I had a gun. They would never say that. ${ }^{93}$

Although this was an isolated incident which did not represent the overall sentiments of the ex-service community, it still demonstrates that military service was not the perfect escape from the wider racial attitudes of Australian society and some servicemen still held prejudicial attitudes, even if they did not overtly express them during the Vietnam War.

In conclusion, the Army was not able to rescue Dave from the cycle of disengagement and anti-social behaviour so common among Stolen Generations survivors. Dave Cook's story suggests new questions of inquiry for historians of both the Stolen Generations and of military history. Following Goodall's suggestion, this article 'take[s] the risk of not knowing the answers to all the questions at the outset'. ${ }^{94}$ Dave Cook's life story does not automatically correspond to every Stolen ex-serviceperson, just as there is no one 'model'

90 Cook, interview with Riseman, 2010, transcript: 23.

91 Cook, interview with Riseman, 2010, transcript: 25.

92 National Inquiry into the Separation of Aboriginal and Torres Strait Islander Children from their Families (Australia) 1997: 222-225.

93 Cook, interview with Riseman, 2010, transcript: 27.

94 Goodall 2002: 24. 
Stolen Generations case. Nevertheless, his life story indicates that broadening oral history research into the experiences of Aboriginal and Torres Strait Islander service personnel can widen historical and contemporary understandings of the impact of military service on Indigenous people. Dave Cook's life story suggests that the argument of the Army as an 'escape' for Aboriginal people has its limitations. To summarise in Dave's own words:

Don't get me wrong. I was no angel; you know what I mean? But because everything just sort of went haywire from the organised life I had in the Army to the disorganised life that I had out in civilian street. ${ }^{95}$

\section{References}

\section{Unpublished sources}

Bostock, George 1991a, 'Black Veterans of Vietnam', unpublished manuscript, Australian Institute for Aboriginal and Torres Strait Islander Studies (AIATSIS), Canberra.

Bostock, George 1991b, Interviews with Aboriginal Vietnam Veterans for proposed book 'Black Veterans of Vietnam', AIATSIS, Canberra.

Cook, David, Interview with Noah Riseman, Raymond Terrace, New South Wales, 20 January 2010.

-, Aborigines Welfare Board file, provided to author by David Cook.

-, Department of Veterans' Affairs Medical File, SS00205, provided to author by David Cook.

-, Service records, service number 214933, Central Army Records Office (CARO), Melbourne.

Egglestone, Private Cedric 'Ned' and Don McLeod, Royal Australian Infantry Corps 1998, interviewed by Bill Bunbury, 3 September 1998, for ABC Radio National Hindsight for program 'Korea, 1950-1953, The Forgotten War', RSL Reservoir, Australian War Memorial AWM 501907.

'To Remove and Protect', AIATSIS, online, accessed 30 June 2010: <http:// www1.aiatsis.gov.au/exhibitions/removeprotect/index.html\#>

95 Cook, interview with Riseman, 2010, transcript: 12. 


\section{Published sources}

Australia 1991, Royal Commission into Aboriginal Deaths in Custody, vol 2, Australian Government Publishing Service, Canberra, accessed 5 November 2010: <http:/ / www.austlii.edu.au/au/other/IndigLRes/rciadic/national/ vol2>

Ball, Desmond (ed) 1991, Aborigines in the Defence of Australia, ANU Press, Canberra.

Beresford, Quentin 2006, Rob Riley: An Aboriginal Leader's Quest for Justice, Aboriginal Studies Press, Canberra.

Boman, Bruce 1982, 'The Vietnam veteran ten years on', Australian and New Zealand Journal of Psychiatry 16: 107-127.

Bradford, Clare 2001, Reading Race: Aboriginality in Australian Children's Literature, Melbourne University Press, Melbourne.

Bray, George, Kenny Laughton, and Pat Forster 1995, Aboriginal Ex-Servicemen of Central Australia, IAD Press, Alice Springs.

Burstall, Terry 1990, A Soldier Returns: A Long Tan Veteran Discovers the Other Side of Vietnam, University of Queensland Press, St Lucia, Queensland.

Carroll (RL), Colonel OM (Max) 1992, 'They were foremost Australian soldiers: an oral account of Aboriginal and Thursday Island soldiers who served in Malaya and Vietnam: 1957 to 1967', Aboriginal History 16(1): 99-105.

Commonwealth of Australia 2004, Forgotten Australians: A report on Australians who experienced institutional or out-of-home care as children, Senate, Community Affairs Reference Committee, accessed 5 November 2010: <http://www. aph.gov.au/senate/committee/clac_ctte/completed_inquiries/2004-07/ inst_care/report/>

Department of Veterans' Affairs 1998-99, Morbidity of Vietnam Veterans: A Study of the Health of Australia's Vietnam Veteran Community: Volume 1 - Male Vietnam Veterans, Australian Government, Canberra, accessed 16 July 2010: <http:/ / www.dva.gov.au/aboutDVA/publications/health_research/morbidity/ males/Pages/v_oneindex.aspx>

Erlinder, C Peter 1984, 'Paying the price for Vietnam: post-traumatic stress disorder and criminal behavior', Boston College Law Review 25, March: 305347.

Foley, Dennis 2003, 'Indigenous epistemology and Indigenous standpoint theory', Social Alternatives 22(1), Spring: 44-52. 
- 2005-06, 'Indigenous standpoint theory: an acceptable academic research process for indigenous academics', International Journal of the Humanities 3(8): $25-36$.

The Forgotten 2003, directed by Glen Stasiuk, originally aired as an episode of Message Stick on the Australian Broadcasting Corporation (ABC), 27 April 2003, videocassette.

Giblett, Noel (ed) 1990, Homecomings: Stories from Australian Vietnam Veterans and their Wives, AGPS, Canberra.

Goodall, Heather 2002, 'Too early yet or not soon enough? Reflections on sharing histories as process', Australian Historical Studies 33(118): 7-24.

Gordon, Harry 1965, The Embarrassing Australian: The Story of an Aboriginal Warrior, Lansdowne Press Pty Ltd, Melbourne.

Grey, Jeffrey 2001, The Australian Army: The Australian Centenary History of Defence Volume I, Oxford University Press, South Melbourne.

- 2010, 'In every war but one? Myth, history and Vietnam', in Zombie Myths of Australian Military History, Craig Stockings (ed), University of New South Wales Press, Sydney: 190-212.

- and Jeff Doyle 1992, Vietnam: War, Myth and Memory: Comparative Perspectives on Australia's War in Vietnam, Allen \& Unwin, Sydney.

Haebich, Anna 2000, Broken Circles: Fragmenting Indigenous Families 1800-2000, Fremantle Arts Centre Press, Fremantle, Western Australia.

- 2008, Spinning the Dream: Assimilation in Australia, 1950-1970, Fremantle Press, North Fremantle.

Hall, Robert 1995, Fighters from the Fringe: Aborigines and Torres Strait Islanders Recall the Second World War, Aboriginal Studies Press, Canberra.

- 1997, The Black Diggers: Aborigines and Torres Strait Islanders in the Second World War, 2nd edition, Aboriginal Studies Press, Canberra.

Harrison, Harold, as told to Michele and Jack Miller 2002, Living in Two Cultures: Memories of Harold Harrison, Bournda Environmental Education Centre, Kalaru, New South Wales.

Huggonson, David 1993, 'Aboriginal Diggers of the 9th Brigade. First AIFAustralia. Army. Australian Imperial Force, (1914/ 1921)', Journal of the Royal Australian Historical Society 79(3-4): 214-225. 
I Hope the War Will be Over Soon 1988, directed by John Ruane, produced and edited by John Tristram and I James Wilson, DVD, Juniper Films.

Jackomos, Alick and Derek Fowell 1993, Forgotten Heroes: Aborigines at War from the Somme to Vietnam, Victoria Press, South Melbourne.

James, Jan ‘Kabarli’ 2010, Forever Warriors, Scott Print, Perth.

Kartinyeri, Doreen 1996, Ngarrindjeri Anzacs, Aboriginal Family History Project, South Australian Museum and Raukkan Council, Adelaide.

Kruger, Alec and Gerard Waterford 2007, Alone on the Soaks: The Life and Times of Alec Kruger, IAD Press, Alice Springs.

MacGregor, Sandy, as told to Jimmy Thomson 1993, No Need for Heroes, CALM Pty Limited, Lindfield, New South Wales.

Maddock, Kenneth (ed) 1991, Memories of Vietnam, Random House, Sydney.

McGregor, Malcolm 2010, 'An army at dusk: the Vietnam-era army comes home', in Raise, Train and Sustain: Delivering Land Combat Power. Chief of Army History Conference 2009, Peter Dennis and Jeffrey Grey (eds), Australian Military History Publications, Canberra: 180-203.

McKay, Gary 1987, In Good Company: One Man's War in Vietnam, Allen \& Unwin, Crows Nest, New South Wales.

Moremon, John 2003, 'Indigenous Australians at war', Agora 38(1): 6-9.

Muir, Kristy 2003, 'The hidden cost of war: the psychological effects of the second world war and Indonesian confrontation on Australian veterans and their families', PhD Thesis, School of History and Politics, University of Wollongong, Wollongong.

- 2007,'Public peace, private wars: the psychological effects of war on Australian veterans', War \& Society 26(1): 61-78.

Murray, Suellen, John Murphy, Elizabeth Branigan and Jenny Malone 2008, After the Orphanage: Life Beyond the Children's Home, University of New South Wales Press, Sydney.

Nakata, Martin 2007, Disciplining the Savages, Savaging the Disciplines, Aboriginal Studies Press, Canberra. 
National Inquiry into the Separation of Aboriginal and Torres Strait Islander Children from their Families (Australia) 1997, Bringing Them Home: Report of the National Inquiry into the Separation of Aboriginal and Torres Strait Islander Children from Their Families, Human Rights and Equal Opportunity Commission, Sydney.

Norst, Marlene J 1999, Burnum Burnum: A Warrior for Peace, Kangaroo Press, East Roseville, New South Wales.

Parliament of Australia 1986, Senate Hansard, Parliament no 34, 21 October 1986: 1628, accessed: 16 July 2010 <http:/ / parlinfo.aph.gov.au>

Pierce, Peter, Jeff Doyle and Jeffrey Grey (eds) 1991, Vietnam Days: Australia and the Impact of Vietnam, Penguin, Ringwood, Victoria.

Pratt, Rod 1990, “"By cripes! I'll fight for white Australia!” Queensland Aborigines in the First A.I.F.', Master of Literary Studies Thesis, University of Queensland, Brisbane.

Ramsland, John 2004, 'Bringing up Harry Penrith: injustice and becoming Burnum Burnum', Education Research and Perspectives 31(2): 94-106.

- 2006, 'The Aboriginal Boys' Training Home, Kinchela, 1924-1970, and the development of a culture of physical fitness and sport', Journal of Educational Administration and History 38(3): 237-248.

- and Christopher Mooney 2006, Remembering Aboriginal Heroes: Struggle, Identity and the Media, Brolga Publishing, Melbourne.

Read, Peter 1999, A Rape of the Soul So Profound: The Return of the Stolen Generations, Allen \& Unwin, Sydney.

Rigney, Lester-Irabinna 1999, 'Internationalization of an indigenous anticolonial cultural critique of research methodologies: a guide to indigenist research methodologies and its principles', Wicazo Sa Review 14(2), Autumn: 109-121.

Sears, Jason 2001, '1919-1929: An Imperial Service', in The Royal Australian Navy: The Australian Centenary History of Defence Volume III, David Stevens (ed), Cambridge University Press, South Melbourne: 55-79.

Shulze, Terry 1987, 'Vietnam post traumatic stress disorder and criminal behaviour', Law Society Journal 25(7): 38-40.

Simon, William, Des Montgomerie and Jo Toscano 2009, Back on the Block: Bill Simon's Story, Aboriginal Studies Press, Canberra. 
Smith, Hugh 2001, 'Minorities and the Australian Army: overlooked and underrepresented?', in A Century of Service: 100 Years of the Australian Army. The 2001 Chief of Army's Military History Conference, Peter Dennis and Jeffrey Grey (eds), Army History Unit, Department of Defence, Canberra: 129-149.

Somerville, Margaret and Tony Perkins 2003, 'Border work in the contact zone: thinking Indigenous/non-Indigenous collaboration spatially', Journal of Intercultural Studies 24(3): 253-266.

Stasiuk, Glen 2004, "“Warriors then...warriors still”: Aboriginal soldiers in the 20th Century', Journal of Australian Indigenous Issues 7(3): 3-13.

Thomson, Alistair 2006, 'Anzac stories: using personal testimony in war history', War \& Society 25(2): 1-21.

Tuhiwai Smith, Linda 1999, Decolonizing Methodologies: Research and Indigenous Peoples, University of Otago Press, Dunedin.

Who Killed Malcolm Smith? 1992, produced and directed by Nicholas Adler and Caroline Sherwood, videocassette, Film Australia, Lindfield, New South Wales.

Winegard, Timothy 2009, 'A case study of Indigenous Brothers in Arms during the First World War', Australian Army Journal 6(1), Autumn: 191-206. 